Care: Jurnal Ilmiah Ilmu Kesehatan Vol .8, No.1, 2020, hal 39-47

Tersedia online di https://jurnal.unitri.ac.id/index.php/care

ISSN 2527-8487 (online)

ISSN 2089-4503 (cetak)

\title{
HUBUNGAN SELF CARE DENGAN KUALITAS HIDUP PASIEN GAGAL JANTUNG DI RSD MANGUSADA
}

\author{
Ida Ayu Agung Laksmi ${ }^{1}$, Made Ani Suprapta ${ }^{2)}$, Ni Wayan Surinten ${ }^{3)}$ \\ 1),2) STIKES Bina Usada Bali. Jalan Padang Luwih Dalung, Bali. \\ ${ }^{3)}$ RSD Mangusada, Jalan Raya Kapal, Mangupura-Badung, Bali. \\ E-mail: agunglaksmi41@,gmail.com
}

\begin{abstract}
Long term of heart failure symptoms will affect the patient functional status and ability to do self-care appropriately. Decreasing functional status and self-care ability will certainly affect the quality of life of patients. This study aimed to determine the relationship of self-care with the quality of life of heart failure patients that undergoing treatment at Heart Polyclinic of Mangusada Hospital. The research design was descriptive correlational using cross sectional approach. The study was conducted in January-February 2019. Total respondent participated were 61 respondents and were taken using a purposive sampling technique. Self care of heart index (SCHFI) questionnaire and the Minnesota Living With Heart Failure Questionnaire (MLHFQ) were used. The results showed that the average of self-care score was 45.25 and the average score of the quality of life was 60.67. Analysis using the Spearman Rank test obtained p-value $=0,000$ and $r=0.506$. It can be concluded that self care had a significant correlation on quality of life patients with heart failure in Mangusada Hospital. We recommended that nursing service providers play an active role in providing education and motivation to heart failure patients to improve self-care abilities.
\end{abstract}

Keywords : Heart failure; self care; quality of life.

\begin{abstract}
ABSTRAK
Gejala jangka panjang yang timbul pada pasien dengan gagal jantung akan mempengaruhi status fungsional pasien dan kemampuan perawatan diri secara tepat. Penurunan status fungsional dan kemampuan perawatan diri dapat mempengaruhi kualitas hidup pasien. Penelitian ini bertujuan untuk mengetahui hubungan self-care dengan kualitas hidup pasien gagal jantung di Poliklinik Jantung Rumah Sakit Mangusada. Desain penelitian adalah deskriptif korelasional dengan menggunakan pendekatan cross sectional. Penelitian ini dilakukan pada Januari-Februari 2019. Total responden yang berpartisipasi adalah 61 responden dan diambil menggunakan teknik purposive sampling. Instrumen yang digunakan adalah kuisioner perawatan diri indeks jantung (SCHFI) dan kuisioner hidup
\end{abstract}

Cara mengutip: Laksmi, Ida A. Agung., Suprapta, M. Ani \& Surinten, Ni Wayan. (2020). Hubungan Self Care dengan Kualitas Hidup pasien Gagal Jantung di RSD Mangusada. Care:Jurnal Ilmiah Ilmu Kesehatan, 8(1), 39-47 
minnesota (MLHFQ). Hasil penelitian menunjukkan bahwa skor perawatan diri rata-rata adalah 45,25 dan skor rata-rata kualitas hidup adalah 60,67. Analisis menggunakan uji Spearman Rank diperoleh nilai $\mathrm{p}=0,000$ dan $\mathrm{r}=0,506$. Dapat disimpulkan bahwa self care memiliki korelasi signifikan terhadap kualitas hidup pasien gagal jantung di Rumah Sakit Daerah Mangusada. Hasil penelitian ini diharapkan mampu mendorong penyedia layanan keperawatan memainkan peran aktif dalam memberikan pendidikan dan motivasi kepada pasien gagal jantung dalam meningkatkan kemampuan self care.

Kata Kunci : Gagal jantung; self-care; kualitas hidup.

\section{PENDAHULUAN}

Gagal jantung merupakan sindrom klinis yang bersifat komplek dengan karakteristik penurunan kemampuan jantung dalam memompa darah untuk memenuhi kebutuhan oksigen dalam tubuh (Smeltzer and Bare, 2010). Meskipun terapi dan pencegahan telah mengalami kemajuan yang pesat, tetapi mortalitas dan mobiditas tetap tinggi dan kualitas hidup penderita masih rendah (Savarese dan Lung, 2016)

Gejala gagal jantung berupa sesak nafas, bengkak, dan kelelahanyang berlangsung lama mempengaruhi status fungsional dan kehidupan yang dijalani pasien setiap hari. Status fungsional yang rendah akan menyebabkan menurunnya kemampuan self care pasien (Mahanani, 2017). Beberapa penelitian seperti yang telah dilakukan oleh Britz dan Dunn (2010);Kaawooan (2012); serta Wahyuni dan Kurnia (2014) menunjukkan pasien gagal jantung mengalami masalah dalam melakukan self care.

Seiring dengan lamanya menderita gagal jantung, beratnya kondisi dan kurangnya dukungan keluarga dapat menyebabkan penurunan kualitas hidup pasien gagal jantung (Burutcu \& Mertz, 2013). Beberapa penelitian menunjukkan kualitas hidup pasien gagal jantung cukup rendah, salah satunya penelitian dari Tatukude, Rampengan, dan Panda (2016) bahwa dari38 pasien gagal jantung yang memiliki kualitas hidup kurang baik sebanyak 24 responden $(63,2 \%)$.

Prevalensi gagal jantung di provinsi Bali sebesar $0.3 \%$ dari populasi sedangkan di kabupaten Badung sebesar 0.1\% (Depkes RI, 2013). Data pasien gagal jantung di RSD Mangusada Badung (2018) menunjukkan jumlah penderita gagal jantung mengalami peningkatan. Studi pendahuluan yang dilakukan pada 10 orang responden yang diberikan kuisioner 
Care: Jurnal Ilmiah Ilmu Kesehatan Vol .8, No.1, 2020, hal 39-47

SCHFI dan MLHFQ didapatkan rata-rata nilai self care responden 45.2 (dari skor maksimal 80) dan sebanyak $60 \%$ responden memiliki self care yang buruk. Begitu juga pada data kualitas hidup ditemukan rata -rata nilai kualitas hidup responden sebesar 42.2 (dari skor maksimal 80) dimana 60\% dari mereka termasuk katagori buruk.

Data tersebut menunjukkan bahwa, manajemen self care yang buruk juga diikuti dengan kualitas hidup yang buruk. Berdassarkan hal tersebut, peneliti tertarik untuk menganalisis hubungan self care dengan kualitas hidup pasien gagal jantung di RSD Badung Mangusada.

\section{METODE PENELITIAN}

Penelitian ini termasuk dalam penelitian deskriptif analitik korelasional dan menggunakan rancangan cross sectional. Sampel yang terlibat adalah pasien gagal jantung yang menjalani perawatan di Poliklinik Jantung RSD Badung Mangusada sebanyak 61 orang. Sampel tersebut dipilih dengan teknik purposive sampling dengan beberapa kriteria inklusi diantaranya pasien yang menderita gagal jantung lebih dari 6 bulan dan mampu berkomunikasi dengan peneliti dengan bahasa tulis atau lisan, sedangkan kriteria eksklusi adalah pasien yang mengalami gejala akut gagal jantung seperti sesak nafas, pusing, lemas dan gejala akut lainnya. Proses pengumpulan data dilaksanakan mulai tanggal 1 Januari sampai 1 Februari 2019. Penelitian ini telah dinyatakan laik etik oleh Komisi Etik Penelitian Kesehatan Stikes Bina Usada Bali dibuktikan oleh surat keterangan lolos kaji etik no 066/EA/KEPK-BUB2018.

Pengukuran self care dengan kuisioner self care of heart failure index (SCHFI) versi 6 yang terdiri dari self care maintenance, self care management) dan self care confidence (Riegel, Lee, Dickson, \& Carlson, 2009). Sedangkan penilaian kualitas hidup menggunakan kuisioner minnesota living with heart failure questionnaire (MLHFQ) versi Indonesia yang telah teruji validitas dan reliabilitas. MLHFQ terdiri dari 21 pertanyaan dengan 6 poin skala likert (Skor 0-5) yang terdiri dari 8 pertanyaan pada dimensi fisik, 5 pertanyaan dimensi emosional dan 8 pertanyaan dimensi kualitas hidup secara umum yang dikembangkan khusus untuk mengevaluasi perkembangan penyakit dan perawatan pada kualitas hidup pasien gagal jantung. Semakin tinggi skor MLHFQ mengindikasikan tingginya efek negatif dari gagal jantung yang dialaminya terhadap kualitas hidup pasien (Kusuma, 
et. al., 2019). Seluruh data hasil penelitian dianalisa dengan analisis deskriptif tetapi untuk variabel self care dan kualitas hidup dikorelasikan dengan uji korelasi non parametrik Rank Spearman karena data tidak terdistribusi normal. Tingkat kepercayaan dalam analisis data ini sebesar 95\% dan nilai alpha $0.05(5 \%)$

\section{HASIL}

Responden dalam penelitian ini adalah 61 pasien gagal jantung baik laki-laki maupun perempuan yang berobat ke Poliklinik Jantung RSD Badung Mangusada. Pengumpulan data dilaksanakan mulai tanggal 1 Januari sampai 1 Februari 2019. Analisis data dilakukan dengan analisis univariate untuk mengetahui karakteristik responden dan analisis bivariat untuk menganalisis hubungan kedua variabel dengan menggunakan uji korelasi non parametrik Rank Spearman.

Tabel 1. Karakteristik responden berdasarkan jenis kelamin dan usia

\begin{tabular}{ccc}
\hline Variabel & $\mathbf{f}$ & $\mathbf{( \% )}$ \\
\hline Jenis Kelamin & & \\
Laki-laki & 40 & 65,6 \\
Perempuan & 21 & 34,4 \\
\hline Usia (tahun) & & \\
$40-50$ & 8 & 13,2 \\
$51-60$ & 33 & 54,1 \\
$61-70$ & 16 & 26,2 \\
$>70$ & 4 & 6,5 \\
Hasil & 61 & 100 \\
\hline
\end{tabular}

Berdasarkan Tabel 1, dapat dilihat dari 61 orang responden, sebagian besar adalah laki-laki yaitu sebanyak 40 orang (65.6\%). Tabel 1 dan 2 diketahui sebagian besar responden adalah laki-laki yang berada pada rentang umur antara 51-60 tahun dan gejala dirasakan selama 21 bulan.

Tabel 2. Karakteristik Responden Menurut Lama Mederita Gagal Jantung

\begin{tabular}{|c|c|c|c|c|}
\hline \multirow[b]{2}{*}{ Variabel } & \multicolumn{4}{|c|}{ Deskripsi } \\
\hline & $\mathrm{N}$ & Min & Maks & $\begin{array}{c}\text { Rerata } \\
+\mathrm{SD}\end{array}$ \\
\hline $\begin{array}{l}\text { Lama } \\
\text { mengalami } \\
\text { gejala } \\
\text { (bulan) }\end{array}$ & 61 & 10 & 55 & $\begin{array}{c}21.56 \pm \\
9.82\end{array}$ \\
\hline
\end{tabular}

Tabel 3 menunjukkan bahwa dari 61 responden, terdapat nilai self care terendah adalah 27 dan tertinggi 70 dengan ratarata skor 45.25. Hal ini berarti bahwa dari 61 orang responden, rata-rata memiliki masih ada yang memilki kemampuan self care yang kurang. Pada variable kualitas hidup terdapat nilai terendah 50 dan tertinggi 75 dan dengan rata-rata 60.67. Hal ini menunjukkan bahwa rata-rata kualitas hidup pasien cukup baik.

Tabel 3. Gambaran Self Care dan Kualitas Hidup Berdasarkan Skor Kuisioner SCHFI dan Skor Kuisioner MLHFQ

\begin{tabular}{ccccc}
\hline Variabel & $\mathrm{N}$ & $\begin{array}{c}\text { Rerata } \pm \\
\text { SD }\end{array}$ & Min & Maks \\
\hline Self Care & 61 & $\begin{array}{c}45.25 \pm \\
9,82\end{array}$ & 27 & 70 \\
\hline $\begin{array}{c}\text { Kualitas } \\
\text { Hidup }\end{array}$ & 61 & $60.67 \pm 7,56$ & 50 & 75 \\
\hline
\end{tabular}


Care: Jurnal Ilmiah Ilmu Kesehatan Vol .8, No.1, 2020, hal 39-47

Hasil uji normalitas data ditunjukkan pada tabel 4 dengan nilai $\mathrm{p}<0.05$ pada kedua variable baik self care maupun kualitas hidup, sehingga uji bivariate dianalisis dengan uji spearman rank.

Tabel 4. Hasil Uji Normalitas Data

\begin{tabular}{ccc}
\hline \multirow{2}{*}{ Variabel } & \multicolumn{2}{c}{ Kolmogorov-Smirnov } \\
\cline { 2 - 3 } & $\mathrm{N}$ & $\mathrm{p}$ \\
\hline Self Care & 61 & 0.045 \\
\hline $\begin{array}{c}\text { Kualitas } \\
\text { Hidup }\end{array}$ & 61 & 0.001 \\
\hline
\end{tabular}

Berdasarkan hasil analisis uji korelasi rank spearman pada tabel 5, menunjukkan ada korelasi yang signifikan antara variabel self care dengan kualitas hidup dengan nilai signifikansi (Sig. (2-tailed)) $\mathrm{p}=0.001$ $(\mathrm{p}<0.05)$, mempunyai korelasi cukup kuat dengan koefisien korelasi sebesar 0.506 (nilai r diantara 0,25-0,59) dan mempunyai arah korelasi yang positif.

Tabel 5. Korelasi Variabel Self Care dengan Kualitas Hidup

\begin{tabular}{cccc}
\hline Variabel & Rerata \pm SD & $\mathrm{p}$ & $\mathrm{r}$ \\
\cline { 1 - 2 } Self care & $45,25 \pm 9.82$ & & \\
$\begin{array}{c}\text { Kualitas } \\
\text { Hidup }\end{array}$ & $60,67 \pm 7.56$ & 9,82 & 0.506 \\
\hline
\end{tabular}

\section{PEMBAHASAN}

Dari 61 responden, terdapat nilai self care terendah adalah 27 yang berarti bahwa terdapat responden dengan kemampuan self care yang kurang dan nilai tertinggi 70 yang berarti bahwa terdapat pula responden dengan kemampuan self care yang baik. Rerata skor self care adalah 45.25 yang berarti bahwa rata-rata responden memiliki self care yang sedang.

Self care merupakan wujud perilaku seseorang dalam mempertahankan kesehatan, perkembangan dan kehidupan disekitarnya (Baker \& Denyes, 2008). Teori self care menyatakan bahwa perilaku perawatan diri merupakan sebuah pengambilan keputusan alami yang dipengaruhi karakteristik individu seperti usia, jenis kelamin, dan pendidikan; masalah seperti penyakit penyerta; dan lingkungan berupa dukungan social. (Riegel, Dickson, \& Faulkner, 2016). Self care dapat dilihat dari 3 dimensi yaitu dimensi pemeliharaan diri (self care maintenance), pengelolaan diri (self care management) dan kepercayaan diri (self care confidence) (Riegel, et al, 2009).

Penyakit gagal jantung yang dialami pasien mempengaruhi individu yang sakit secara holistic baik secara biologis ataupun psikologis. Sebagian besar pasien mengenal penyakitnya saat gejala yang dirasakan sudah berat dan hanya beberapa yang mampu mengenal gejala dini penyakitnya sampai dapat menyebabkan pasien ini tidak mampu lagi untuk merawat diri (Wahyuni \& Kurnia, 2014). Oleh karena itu, didapatkan gambaran self care responden yang berbeda-beda. 
Selain itu, jika dilihat dari karakteristik responden, sebagian besar responden adalah laki-laki yang berada pada rentang usia antara 51-60 tahun dengan gejala dirasakan selama 21 bulan. Hal ini sesuai dengan teori Self Care Orem bahwa kemampuan individu untuk melakukan self care dipengaruhi oleh basic conditioning factors seperti; umur, jenis kelamin, status perkembangan, pola kehidupan status kesehatan, sistem perawatan kesehatan, sistem keluarga, lingkungan serta orientasi sosial budaya (Muhlisin \& Irdawati, 2010).

Pada penelitian ini juga didapatkan bahwa dari 61 orang responden, rata-rata memiliki skor kualitas hidup 60.67 yang artinya berada pada kategori cukup baik. Kualitas hidup merupakan sebuah konsep yang disusun untuk menjelaskan penilaian subjektif bagaimana sebuah penyakit yang dialami oleh seorang mempengaruhi individu secara keseluruhan meliputi kepribadian, kemampuan adaptasi serta harapan untuk hidup sehat (Barutcu \& Mert, 2013)

Kualitas hidup pasien dengan gagal jantung pada umumnya menurun dikarenakan keterbatasan berbagai fungsi yang dialami oleh pasien (Moser \& Riegel, 2008).. Fluktuasi kondisi yang dialami pasien gagal jantung menimbulkan suatu tekanan emosional dan gangguan pada kualitas hidup terkait kesehatan pasien gagal jantung (Kunts, 2006 dalam Wahyuni \& Kurnia, 2014). Rendahnya kualitas hidup pasien juga dapat dipengaruhi oleh berbagai hal, diantaranya karekteristik responden yang terdiri dari usia, jenis kelamin, pendidikan, pekerjaan, dan sosial ekonomi; koping; depresi; dan kecemasan (Rochmayanti, 2011). Pada penelitian ini, sebagian besar responden berusia $>50$ tahun dan rata-rata menderita gagal jantung lebih dari 1 tahun. Kedua factor ini berkontribusi terhadap nilai kualitas hidup yang rata-rata cukup baik.

Berdasarkan uji korelasi non parametrik Rank Spearman di dapatkan nilai $\mathrm{p}=0.000$ $(\mathrm{p}<0.05)$ dan koefisien korelasi sebesar 0.506 (tabel 5.6). Artinya self care berpengaruh secara signifikan terhadap kualitas hidup dengan kekuatan korelasi sedang dan berarah postif, yaitu semakin tinggi kemampuan self care penderita gagal jantung maka semakin baik kualitas hidupnya.

Hasil penelitian ini mendukung beberapa hasil penelitian sejenis diantaranya; penelitian Kaawoan (2012) terdapat hubungan yang signifikan antara kemampuan self care dengan kualitas hidup 
Care: Jurnal Ilmiah Ilmu Kesehatan Vol .8, No.1, 2020, hal 39-47

pasien CHF di RSUP Prof Dr R D Kandou Manado dengan nilai $\mathrm{p}=0,013$ dan $\mathrm{r}=0,013$ dan penelitian Artama tahun 2017 di RSP Universitas Hasanuddin didapatkan korelasi yang signifikan $\mathrm{p}=0.010$ dan $\mathrm{r}=0,766$ pada variabel self care dan kualitas hidup pasien gagal jantung. Penelitian yang dilakukan oleh Britz dan Dunn (2010), menunjukkan kemampuan self care dapat meningkatkan kualitas hidup pasien begitu juga sebaliknya.

Dalam penelitian ini, sebagian besar responden menjawab komponen self care management dan self care confidence dengan nilai yang rendah, sedangkan untuk self care maintenance seperti kepatuhan dalam pengobatan, mengikuti petunjuk diet rendah garam dan membatasi masukan cairan, rata-rata responden memilih "sering" dengan nilai 3 dari nilai maksimal 4.

Self care sangat penting bagi pasien dengan penyakit kronis, seperti halnya pada pasien gagal jantung. Pengalaman yang didapatkan oleh pasien gagal jantung dapat meningkatkan pengetahuan pasien terkait gejala dan tanda penyakit yang memengaruhi kemampuan self care (Jang, 2009 dalam Kawooan, 2012). Kemampuan self care yang diperoleh melalui pengalaman menderita penyakit kronis akan berdampak pada perubahan gaya hidup dan kualitas hidup pasien itu sendiri (Smeltzer, Bare, Hinkle, \& Cheever, 2010). Adanya perubahan fisiologis pada penyakit kronis dapat berdampak pada perubahan kualitas hidup seseorang (Black \& Hawks, 2009).

Kemampuan self care pasien gagal jantung mempunyai peranan sangat penting dalam mempengaruhi kualitas hidup penderita. Perubahan self care akan searah dengan perubahan kualitas hidup. Faktor-faktor yang mempengaruhi self care tidak hanya faktor fisiologis (penurunan kapasitas fungsional) tetapi faktor juga faktor lain seperti faktor pengetahuan, kondisi psikologis (kecemasan), dukungan sosial, peran penderita dalam keluarga dan sosial ekonomi. Jawaban kuisiner kualitas hidup yang berhubungan dengan sosialisasi dan dukungan sosial dengan tetangga dan lingkungan pekerjaan (pertanyaan 5,7,8,9) menunjukkan responden dengan kualitas hidup yang baik memiliki aktivitas sosial yang lebih baik.

Self care mempengaruhi kualitas hidup melalui proses belajar (learning proccess) dan perbaikan respon fisiologis. Responden yang memiliki kemampuan self care yang baik, lebih memahami cara perawatan dan 
hal yang harus dilakukan untuk mengatasi stress fisik dan psikologis yang dihadapi. Hal ini terlihat dari jawaban kuisioner responden yang memiliki kualitas hidup yang baik menunjukkan cara perawatan (pertanyaan nomor 10-13 kuisioner self care) yang lebih baik. Hal ini menyebabkan perbaikan respon fisiologis dan psikologis pasien sehingga menyebabkan pasien lebih nyaman, aman dan mandiri (pernyataan kuisioner kualitas hidup no 18 dan 20). Perbaikan respon fisiologis dan psikologis pasien yang berlangsung lama memungkinkan responden untuk terus belajar untuk meningkatkan kemampuan self care. Proses belajar ini membantu responden memperbaiki mekanisme kopingnya dan membuat kualitas hidup responden mejadi lebih baik. Semakin baik motivasi seseorang baik yang berasal dari diri sendiri maupun dari luar diri, maka akan semakin baik pula kualitas hidup pada pasien gagal jantung itu sendiri (Wahyuni \& Kurnia 2014).

\section{KESIMPULAN}

Self care berkorelasi secara signifikan terhadap variabel kualitas hidup pasien gagal jantung di RSUD Badung Mangusada dengan korelasi positif yang cukup kuat dengan nilai $\mathrm{p}=0,000$ dan $\mathrm{r}=0.506$. Semakin tinggi nilai self care, maka semakin tinggi pula kualitas hidup pasien dengan gagal jantung.

\section{SARAN}

Rendahnya self care pasien gagal jantung pada komponen self care management dan self care confidence diharapkan mampu mendorong peran aktif pemberi layanan (khususnya perawat) untuk melaksanakan peran sebagai edukator dan motivator dengan memberikan informasi dan motivasi kepada pasien gagal jantung untuk mempertahankan dan meningkatkan kemampuan self care.

\section{REFERENSI}

Baker, L.K., \& Denyes, M.J. (2008). Predictors of self-care in adolescents with cystic fibrosis: a test of Orem's theories of self-care and self-care deficit. Journal of Pediatric Nursing, 23(1):37-48.

Barutcu, C. D., \& Mert, H. (2013). The relationship between social support and quality of life in patients with heart failure. Journal of the Pakistan Medical Association, 63(4), 463-467.

Black, M. J. \& Hawks, H .J. (2009). Medical Surgical Nursing : Clinical Management For Continuity of Care, 8th Ed. Philadephia : W.B. Saunders Company

Britz, J. A \& Dunn, K.S. (2010). Self Care and Quality Of Life Among Patients With Heart Failure. Journal Of The American Academy of Nursing Practitioners 22,480 - 487

Crawford, M.H. (2009). Current Diagnosis \& Treatment Cardiologi, $3^{\text {rd }}$ ed. United States : McGraw-Hill 
Care: Jurnal Ilmiah Ilmu Kesehatan Vol .8, No.1, 2020, hal 39-47

Companies.

Depkes RI. (2013). Riset Kesehatan Dasar. Jakarta: Badan Penelitian dan pengembangan Kesehatan Kementrian Kesehatan RI

Kaawoan, A.Y.A. (2012). Hubungan SelfCare dan Depresi dengan Kualitas Hidup Pasien Heart Failure di RSUP Prof DR R.D. Kandou Manado. Tesis, Jakarta, Universitas Indonesia.

Kusuma, D. Y., Shatri, H., Alwi, I., \& Abdullah, M. (2019). Validity and Reliability Studies of the Indonesian Version of the Minnesota Living with Heart Failure Questionnaire (MLHFQ): Quality of Life Questionnaire for Patients with Chronic Heart Failure. Acta Medica Indonesiana, 51(1), 26-33.

Mahanani, A.R,. (2017). Gambaran Kualitas Hidup pada Pasien Gagal Jantung Kongestif di Kota Surakarta. Laporan Skripsi. Pogram Studi Keperawatan Fakultas Ilmu Kesehatan Universitas Muhammadiyah Surakarta tahun 2017

Moser, D. K. \& Riegel, B. (2008). Cardiac Nursing: A Companion Braunwald's Heart Disease. Philadelphia: Saunders Elsevier

Muhlisin, A. \& Irdawati. (2010). Teori Self Care dari Orem dan Pendekatan dalam Praktek Keperawatan. Berita Ilmu Keperawatan, 2 (2).

Rochmayanti. (2011). Analisis faktorfaktor yang memengaruhi kualitas hidup pasien jantung koroner di Rumah Sakit Pelni Jakarta. (Tesis). Fakultas Ilmu Keperawatan
Universitas Indonesia.

Savarese, G., Lund, L.H. ( 2017). Global Public Health Burden of Heart Failure. online available at; www.CFRjournal.com diakses 12 Agustus 2018

Smeltzer, S.C. \& Bare, B.G. (2010). Buku Ajar Keperawatan Medikal Bedah. Jakarta : EGC

Smeltzer, S.C., Bare, B.G., Hinkle, J.L., Cheever, K.H. (2008). Brunner \& Suddarth's Textbook o Medical Surgical Nursing. Philadelphia: Lippincott Williams \& Wilkins.

Riegel, B., Dickson, V. V., \& Faulkner, K. M. (2016). The situation-specific theory of heart failure self-care revised and updated. Journal of Cardiovascular Nursing, 31(3), 226235.

https://doi.org/10.1097/JCN.00000 00000000244

Riegel, B., Lee, C. S., Dickson, V. V., \& Carlson, B. (2009). An update on the self-care of heart failure index. Journal of Cardiovascular Nursing, 24(6), 485-497.

https://doi.org/10.1097/JCN.0b013 e3181b4baa0

Tatukude, C., Rampengan, S. H., \& Panda, A. L. (2016). Hubungan tingkat depresi dan kualitas hidup pada pasien gagal jantung. Jurnal EClinic (ECl), 4, 115-121.

Wahyuni, A., \& Kurnia, O. S. (2014). Hubungan Self Care dan Motivasi dengan Kualitas Hidup Pasien Gagal Jantung. Jurnal Kesehatan Masyarakat, 2(2), 108-115. 